\title{
ADMINISTRATION OF MICRO-CREDIT BY NATIONAL BANK
}

\author{
K. Prabakkar Rajkumar*
}

\section{ABSTRACT:}

The United Nations has designated the year 2005 as the "International year of Micro-Credit". The Micro Finance (MF) initiatives of NABARD have evolved as a sustainable social movement over a decade by now. The design and content of these innovations have remained dynamic in tandem with the changing needs of the micro finance sector in the Country. These initiatives have attracled the attention of a wide range of stakeholders. Large number of formal and informal agencies has joined the NABARD in this unique process of socio-economic engineering. The relevance of the micro finance programme was greatly enhanced the interest of all participants through the core strategies of SHG - bank linkage, which was built around a simple but basic aspect of human nature - the feeling of self-worth.

\section{Administration by NABARD}

Administration of Micro Finance by NABARD through the self group bank linkage programme has passed through various phases namely pilot testing (1992 to 1995), mainstreaming (1996 to 1998) and expansion (1998 onwards), and has assumed the shape of a micro-finance movement in India. The phases of SHG Bank-Linkage

* Faculty of Department of Commerce, Periyar University, Salem - 11, Tamil Nadu. 


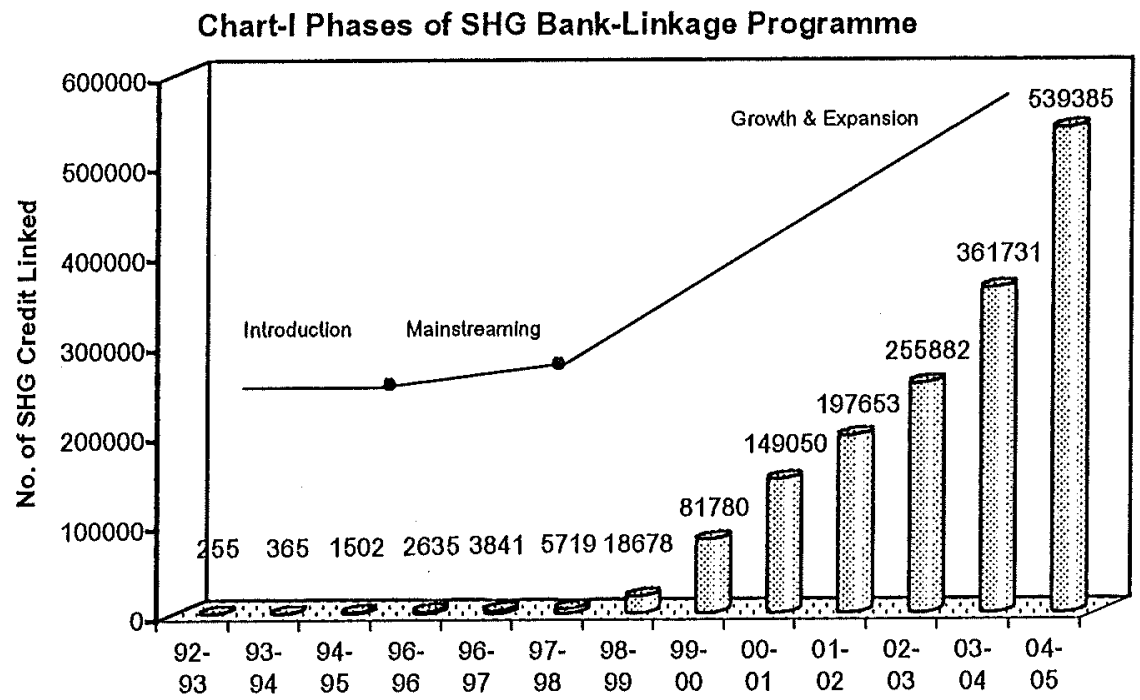

During 2004-05, 5,38,385 new SHGs were credit linked with banks as against $3,61,731$ during 2003-04. The increased percentage is 49 . Under the programme women take active part $(90 \%), 95$ percent of them promptly repay the loan.

Upto 31 March 2005, 242.5 lakh poorhouse holds in the country gained access to $M F$ from the formal banking system. The growth rate is 45 percent over the previous year. The state-wise, growth of SHGs credit linked programme during 2004-05 is given in Table -1 .

\section{Table 1 State-wise Growth of SHGs Credit Linked Programme}

\begin{tabular}{|l|c|}
\hline \multicolumn{1}{|c|}{ States } & $\begin{array}{c}\text { Increased number over the } \\
\text { Previous Year (2003-04) }\end{array}$ \\
\hline Andhra Pradesh & $1,07,351$ \\
\hline Tamil Nadu & 70,437 \\
\hline Karnataka & 59,332 \\
\hline Orissa & 45,668 \\
\hline West Bengal & 41,013 \\
\hline Uttar Pradesh & 40,438 \\
\hline Maharasthra & 32,611 \\
\hline Kerala & 27,081 \\
\hline Rajastan & 26,160 \\
\hline Assam & 20,528 \\
\hline
\end{tabular}

Source: NABARD Annual Report 2004-05. 


\section{Support to Partner Agencies}

NABARD encouraged other partner agencies to contribute their services to promole and nurture of SHGs. During 2004-05, Rs.597.48 Lakh was sanctioned to various agencies and promoted 43,359 SHGs. The cumulative assistance sanctioned was Rs.2,534.34 lakh for promotion of 2.11 lakh SHGs. So far, Rs. 1, 140 .69 lakh has been released. The pilot scheme introduced in 2003 for supporting socially committed Industrial Rural Volunteers (IRVs) to organise the rural poor into SHGs, was extended during 2004-05, to all the 13 priority states. That accounted for the bulk of the rural people. Indira Gandhi National Open University (IGNOU) and Yashwantrao Chavan Maharashtra Open University (YCMOU) conduct programmes on women empowerment and $\mathrm{SHG}_{\text {s }}$ with support from NABARD. The grant assistance extended to various partners in SHG Bank Linkage Programme is given in table-2.

\section{Table 2 Grant Assistance Extended to various Partners in SHG-Bank Linkage Programmo}

\begin{tabular}{|c|c|c|c|c|c|c|c|c|c|}
\hline \multirow{2}{*}{ Agency } & \multicolumn{3}{|c|}{$\begin{array}{l}\text { Sanctions during the } \\
\text { year }\end{array}$} & \multicolumn{3}{|c|}{ Cumulative Sanctions } & \multicolumn{3}{|c|}{ Cumulative Progress } \\
\hline & No. & Amount & $\begin{array}{l}\text { No. of } \\
\text { SHGs }\end{array}$ & No. & Amount & $\begin{array}{l}\text { No. of } \\
\text { SHGs }\end{array}$ & No. & Amount & $\begin{array}{l}\text { No. of } \\
\text { SHGs }\end{array}$ \\
\hline Co-operatives & 26 & 106.33 & 12,560 & 55 & 230.36 & 28.110 & 34.45 & 15,775 & 5.212 \\
\hline $\begin{array}{l}\text { Reglonal } \\
\text { Rural Banks }\end{array}$ & 12 & 29.78 & 3,890 & 102 & 305.54 & 38,935 & 95.79 & 37,711 & 20,716 \\
\hline $\begin{array}{l}\text { Non Govt. } \\
\text { Organizations }\end{array}$ & 317 & 426.58 & 24,234 & 1,179 & $1,938.76$ & $1,39,513$ & 964.31 & $1,05,866$ & 62,710 \\
\hline $\begin{array}{l}\text { Farmers' } \\
\text { Clubs }\end{array}$ & - & - & - & - & - & - & 41.32 & 10,645 & 5,249 \\
\hline $\begin{array}{l}\text { Individual } \\
\text { Rural } \\
\text { Volunteers }\end{array}$ & 10 & 34.77 & 2,675 & 15 & 59.67 & 4,525 & 4.82 & 788 & 395 \\
\hline Total & 365 & 597.48 & 43,359 & 1,351 & $2,534,34$ & $2,11,083$ & $1,140.69$ & $1,70,785$ & 84,282 \\
\hline
\end{tabular}

Source: NABARD Annual Report 2004-05.

\section{Support to Institutions}

NABARD has been providing refinance support to banks for financing MFIs for supporting SHGs. Under bulk lending scheme (formulated in 1993) NABARD extended financial support to NGOs upto Rs. 10 Lakhs through banks. NABARD started providing Revolving Fund Assistance (RFA) to Micro Finance Institutions. RFA is now extended to MFIs for onlending to either self help groups or smaller groups of around 5 members. So far, RFA of Rs.27.32 Crore has been sanctioned to 32 agencies. Out of which Rs. 17.80 Crore has been already released. 


\section{Developmental and Promotional Activities}

The main reason for success of this program is due to adequate financial and technical from NABARD for providing training to staff members of banks, NGOs and Government agencies. It inducts them into the linkage programme and enhances their effectiveness in Micro Financing. During 2004-05, the bank extended support for arranging to conduct.

> 2481 awareness creation and capacity building programmes for 2.08 lakhs SHG members for managing thrift and credit.

- 160 awareness cum refresher programmes for 4246 chief executive officer and field staff of $\mathrm{NGOs.}$

$>7$ trainers' training programmes for 161 faculty members from commercial and co-operative banks. 948 training programmes covering 42,812 officials of Commercial, Regional, Rural and Co-operative Banks.

$>449$ field visits to nearby SHGs for 8204 officials of Block Level Banker's Committee (BLBC) and

> 41 Programmes on MF for 1198 elected members of Panchayath Raj Institutions.

\section{Special Scaling-up Efforts}

Out of the total SHGs credit linked, Andhra Pradesh (30\%), Tamil Nadu (14\%), Karnataka (10\%), Orissa and Uttar Pradesh (7\% each), together accounted for 68 per cent of the total SHGs credit linked and 80 per cent of the total amount of bank loan disbursed. Nearly 59 per cent of the groups linked so far were from southern states. The share of states other than these increased from 28 per cent as on 31 March 2002 to 41 per cent as on 31 March 2005. NABARD's emphasis on scalingup the programme in 13 states that accounted for 70 per cent of the country's rural poor has resulted in two and a half fold increase in the number of SHGs credit linked during the period 2004-05; significant increase was observed in economically backward states like Assam, Bihar and Orissa. The cumulative Growth in SHGBank linkage in priority, state-wise, is given in table -3 . 


\section{Table 3 Cumulative growths in number of SHGs Credit Linkage in Priority States}

\begin{tabular}{|c|l|c|c|c|c|c|}
\hline & & $\begin{array}{c}31 \text { March } \\
2003\end{array}$ & $\begin{array}{c}31 \text { March } \\
2004\end{array}$ & $\begin{array}{c}\text { Increased } \\
\text { over } \\
\text { previous } \\
\text { year }\end{array}$ & $\begin{array}{c}31 \text { March } \\
2005\end{array}$ & $\begin{array}{c}\text { Increased } \\
\% \text { over } \\
\text { previous } \\
\text { year }\end{array}$ \\
\hline 1 & Orissa & 42272 & 77588 & 83 & 123256 & 59 \\
\hline 2 & $\begin{array}{l}\text { Uttar } \\
\text { pradesh }\end{array}$ & 53696 & 79210 & 47 & 119648 & 51 \\
\hline 3 & West Bengal & 32647 & 51685 & 58 & 92698 & 79 \\
\hline 4 & Maharashtra & 28065 & 38535 & 37 & 71146 & 85 \\
\hline 5 & Rajasthan & 22742 & 33846 & 49 & 60006 & 77 \\
\hline 6 & $\begin{array}{l}\text { Madhya } \\
\text { pradesh }\end{array}$ & 15271 & 27095 & 77 & 45105 & 66 \\
\hline 7 & Assam & 3477 & 10706 & 208 & 31234 & 192 \\
\hline 8 & Bihar & 8161 & 16246 & 99 & 28015 & 72 \\
\hline 9 & Gujarat & 13875 & 15974 & 15 & 24712 & 55 \\
\hline 10 & Jharkhand & 7765 & 12647 & 63 & 21531 & 70 \\
\hline 11 & Chhatisgarh & 6763 & 9796 & 45 & 18569 & 89 \\
\hline 12 & $\begin{array}{l}\text { Himachal } \\
\text { pradesh }\end{array}$ & 8875 & 13228 & 49 & 17798 & 34 \\
\hline 13 & Uttaranchal & 5853 & 10908 & 86 & 14043 & 29 \\
\hline
\end{tabular}

Source : NABARD Annual Report 2004-05.

\section{Innovative and Initiative Programmes}

NABARD has initiated many innovative programmes like, introduction of Pilot Projects for improving the outreach as well as sustainability of the programme. During 2004-05 NABARD has initiated a pilot project for promotion of Micro-Enterprises through SGHs in 10 States namely Gujarat (Panchammal District), Himachal Pradesh (Kangra District), Jharkhand (Hazaribagh District), Karnataka (Mysore District), Maharashtra (Chandrapur District) Orissa (Puri District), Rajasthan (Ajmer District), Tamil Nadu (Madurai District), Uttar Pradesh (Rae Bareilly District) and 24 Districts in West Bengal. NABARD encouraged SHG's organised by tribal communities covering 17 villages in two blocks of Kalahandi District to establish three Gramin banks through grant assistance of Rs.2.37 lakh. NABARD established a pilot scheme to test the acceptability and adaptability of Information Technology in rural areas and also address management information system needs in rural banks to envisage the introduction of processor cards and automation of active clients like KCC holders and SHGs. Automation of book-keeping to reduce the paper work and save time and improve the efficiency of field workers. The scheme was launched in five branches of Sri Visaka Grameen Bank at Andhra Pradesh. 
More over 10 village information centers (e-grama) were established in Davangare district at Karnataka. The main aim is, enabling villagers and rural poor access the knowledge in IT and MIS.

\section{Support to Joint Liability Groups (JLGS)}

The small and marginal farmers are very much hurdled in getting financial requirements. The inability of this section can get financial assistance with joint liability. NABARD provides Rs. 3 lakh grant assistance for meeting operational costs for the Joint Liabilities Groups (JLGs) during implementation of the project. So far the participant banks have promoted $293 \mathrm{JLG}$ and financed $285 \mathrm{JLG}$ to the tune of Rs. 447.92 lakh.

The Government of Andhra Pradesh formed Rythu Mithra Groups (RMGs) to promote small, marginal and landless farmers. NABARD has provided liquidity support of Rs. 270 crore for financing new borrowers of RMGs to Andhra Pradesh State Co-operative Banks. During 2004-05, 18 Commercial Banks, 9 Regional Rural Banks, and 9 District Central Co-operative Banks involving a loan amount of Rs.28.1 1 crore assisting 62,000 formers under the project financed 4,437 RMGs.

\section{MF Development Fund}

The Micro-Finance Development Fund was established by NABARD with Rs. 40 crore equally contributed by NABARD and Reserve Bank of India. Moreover, Rs. 20 Crore from 11 Commercial Banks identified by RBI. The fund is being utilized for scaling up various MF initiatives with special focus on capacity building under the SHG-bank linkage programme. During 2004-05, Rs. 6.39 crore was utilized from the fund for various promotion and development of MF.

\section{Changes in Government Policy}

During the year Government of India redesignate the existing Micro Finance Development Fund (MFDF) has Micro Finance Development Equity Fund (MFDEF). For this purpose the fund is further strengthened by Rs.20 Crore, contributed by 11 commercial banks identified by RBI. Thus the Government of India decided to enhance the corpus to Rs. 200 crore. RBI, NABARD and Commercial Bank will contribute the additional amount of Rs. 100 crore, and an Advisory Board consisting of representatives from these institutions will manage fund. 


\section{Utilization and Collaborations}

During 2004-05, Rs.41.51 lakh was utilized for MF innovations from the Credit and Financial Services Fund (CFSF) set up with the assistance of Swiss Agency for Development and Co-operation (SDC). A sum of Rs. 45 lakhs was claimed from Deutsche Gesellschaft for Techmische Zusammanarbeit (GTZ) as the last installment under the NABARD-GTZ project for technical collaboration for supporting training and capacity building initiatives and undertaking exposure visits of which an amount of Rs. 11.91 lakhs was received. The cumulative reimbursement availed from the GTZ aggregated Rs. 531.48 lakhs. The NABARD-GTZ project came to an end on $31^{\text {st }}$ December 2004.

\section{Conclusion}

The initiative and innovative programmes taken by NABARD, stated above, not only enabled SHG member gain access to key financial services like savings and credit, but also helped poor families to get engage in social services, like good health and education, business development services like skill upgradalion and market linkages etc., In addition these groups are also involved in a wide range of micro-enterprises like vermi-composting, livestock rearing, handicrafts, vending of various commodities in rural areas, running public distribution retails outlets, road construction, sanitation and hygiene education in villages, distributing relief materials elc. The micro finance administration of NABARD yielded remarkable success and the SHG bank linkage programme has emerged as the largest micro-finance programme in the world.

\section{References}

- NABARD's Annual Reports (1999-2000 to 2004-05)

- NABARD's State Level Credit Seminar - State Focus Paper (1999-2000 to 2004-05)

- NABARD's Statistical Reports (1999-2000 to 2004-05)

- NABARD's News Letters

- The Hindu Survey of Indian Agricullure-1999,2000,01,02,03, and 2004

- The Economic Times-2005RBI Bulletins (1999-2000 and 2003 -04) 